\title{
33. CENOZOIC BIOSTRATIGRAPHY, PHYSICAL STRATIGRAPHY AND PALEOOCEANOGRAPHY IN THE NORWEGIAN-GREENLAND SEA, DSDP LEG 38 PALEONTOLOGICAL SYNTHESIS
}

\author{
Hans-Joachim Schrader ${ }^{1}$, Kjell Bjфrklund ${ }^{2}$, Svein Manum ${ }^{3}$, Erlend Martini ${ }^{4}$, and Jan van Hinte ${ }^{5}$
}

\section{INTRODUCTION}

Leg 38 sites located in the Norwegian-Greenland Sea encompass a span of $13^{\circ}$ of latitude from $63^{\circ} 21.06^{\prime} \mathrm{N}$ (Site 336) to $76^{\circ} 08.98^{\prime} \mathrm{N}$ (Site 344). They represent a rich source of information relating to marine geologic and biologic events in this adjacent sea from the opening in early Tertiary to the present. The stratigraphic record at each site reflects, in varying degrees, the dynamic evolution of oceanographic, sedimentary, and tectonic processes characteristic of this area.

\section{BIOSTRATIGRAPHY}

Sixteen sites were cored in the Norwegian-Greenland Sea and all sites (354 cores) combined resulted in a fairly complete Eocene-Recent section. No Paleocene or older sediments were recovered. The composite sequence at Site 348 (Recent to Miocene) and Site 338 (Recent to Eocene) represents an excellent biostratigraphic reference section for the NorwegianGreenland Sea and provides a record of major biostratigraphic events spanning a $50 \mathrm{~m} . \mathrm{y}$. interval within this cool-temperate to subarctic province.

Microfossils throughout the sequences at Sites 338 and 348 confirm that deposition during most of the Eocene-Recent interval took place at a bathyal (middle to upper) depth. The uniformity of bathymetric setting is not matched by uniformity of sediment composition and processes. A perusal of the dominant lithologies present within this sequence illustrates that major variations have occurred in terms of composition and thus reflect the dominant mode of sediment accumulation and transport. About 110 meters of terrigenous muds were deposited on acoustic basement at Site 338 with an abrupt change to 210 meters of biogenic siliceous ooze, interrupted by a thin calcareous ooze sequence in the late Oligocene, and followed by 60 meters of a "glacial" sequence. At Site 348 approximately 200 meters of siliceous biogenic sediments overlie 300 meters of terrigenous muds and these are overlain by approximately 60 meters of "glacial" sedi-

\footnotetext{
'Geologisch-Paläontologisches Institut und Museum der Universität, Olshausenstrasse 40/60, D-2300 KIEL, F.R. Germany.

${ }^{2}$ Universitetet i Bergen, Geologisk Institut Avd.B, Olaf Ryesvei 19, 5014 Bergen Universitetet, Norway.

${ }^{3}$ Universitetet i Oslo, Institut for Geologi, Blindern, Oslo 3, Norway.

Geologisch-Paläontologisches Institut der Johann-WolfgangGoethe-Universität, Senckenberg Anlage 32-34, D-6000 Frankfurt, F.R. Germany.

'Esso Production Research European Laboratories, 213 cours Victor-Hugo, 33321 Beglès, France.
}

ments. The biogenic siliceous sequence spans an interval from Eocene to Pliocene. The pattern of biogenic sedimentation prevailing during the Eocene to Miocene abruptly ended within the Pliocene where terrigenous muds, silts, and fine sands interbedded with thin biogenic calcareous/siliceous sequences appear in abundance representing glacially/interglacially controlled sediments.

Figure 1 depicts an encouragingly large number of biostratigraphic zones delineated within the various cored sections of prolifically fossiliferous early Eocene to late Pleistocene sediments encountered at all sites. These zones are a product of both evolution and ecologically induced migration of species representing members of the planktonic microbiota of the northern hemisphere, along with infrequent incursions of species from neighboring (Pacific and North-Atlantic) water masses. The time-scale of Berggren (1972a) and Berggren and van Couvering (1974, p.170) was used as a basis for age determination. However, apart from the calcareous nannofossils and the silicoflagellates, "standard zonal schemes" could not be applied in this high latitude region, and empirical local zonations were established for the different groups of fossils. Our preliminary zonal scheme is given in Figure 1 and discussed below.

Silicoflagellate zones, as well as calcareous nannofossil zones or assemblages, are based on first and last occurrences of species and are, aside from diatoms, the only source of micropaleontologic dating outside the Norwegian-Greenland Sea at a finer resolution scale. In all cases, the occurrences of the index species can be correlated directly to the standard nannoplankton zonation or via reference samples or sections containing both fossil groups for the silicoflagellates (compare Figure 2 in Martini and Müller, this volume).

The diatom zones defined by Schrader (this volume) allow a good scale of biostratigraphic resolution within the Pleistocene-Miocene interval in contrast to the lengthy intervals delineated by silicoflagellates and other zones. This may be due to the differences in rates or evolution of diatoms in cooler provinces as opposed to other groups. Diatom zones are, for the above mentioned interval, tied via the North Pacific Diatom Zonation of Schrader (1973) and Koizumi (1973, 1975) to the Standard Equatorial Pacific Diatom Zonation of Schrader and Burckle (in press) and can thus be correlated to the paleomagnetic stratigraphic record and calibrated to the absolute time scale. All zones below the early Miocene are roughly correlated to outside relevant reference sections. 


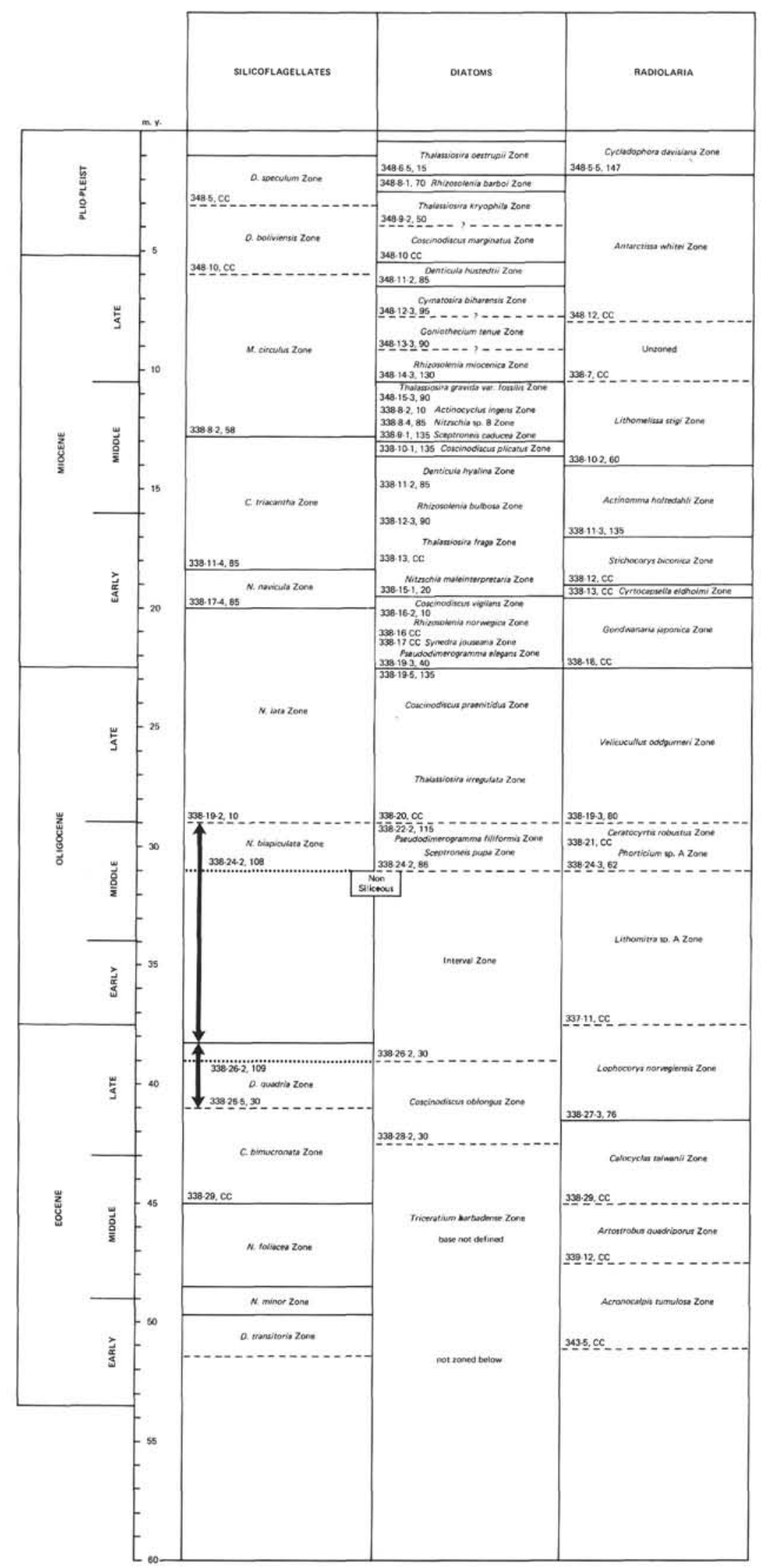

Figure 1. Biostratigraphic zones for Leg 38 sediments. The upper and lower boundaries at sites are presented at which zones are established. To the left are the major geological events in the NorwegianGreenland Sea. 
PALEONTOLOGICAL SYNTHESIS

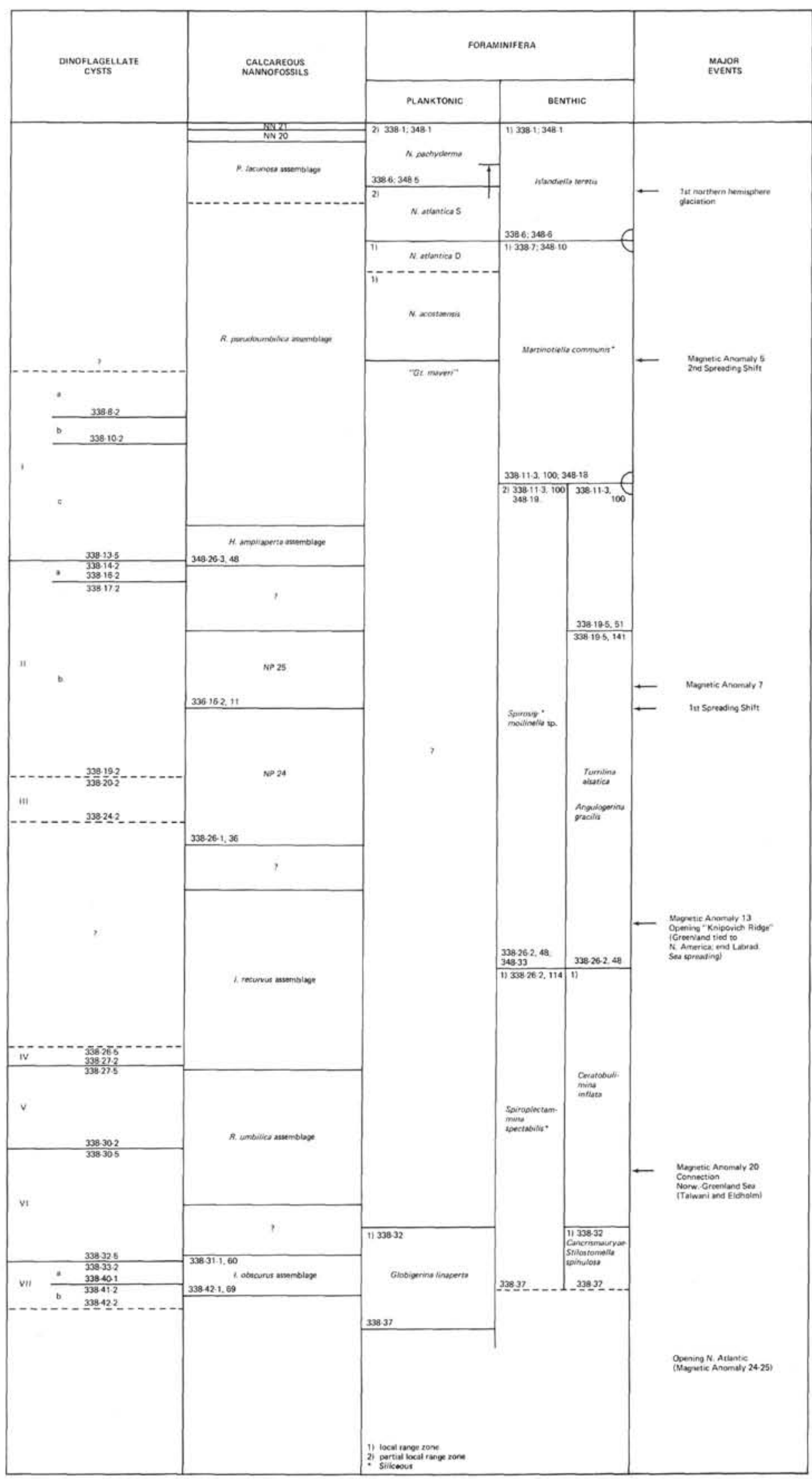

Figure 1. (Continued). 
The standard low latitude radiolarian zonation, applicable for both the Atlantic and Pacific oceans, could not be used for dating Norwegian Sea sediments. All radiolarian zones (Bjфrklund, this volume) are local, total range or partial range zones. By compilation of several sites, 15 radiolarian zones are suggested, in time ranging from the early Eocene to the Recent. Correlations to the time scale have been made via the silicoflagellate/diatom zonation to outside sections.

No applicable standard dinocyst-zonation (Manum, this volume) is available. Based on detailed range studies at Site 338 (early Eocene to middle Miocene), a provisional local zonal scheme was made, which, when applied to other sites, gave reasonably good correlations compared with results obtained with other fossil groups. However, it remains to work out ranges at other sites in greater detail to see which members of the assemblages are most diagnostic before zones can be properly defined.

The age of the dinocyst zones is given mainly with reference to local results based on other fossil groups. Since relatively few species from Leg 38 material have as yet been properly identified, a basis for comparison with previously known ranges is limited. The fact that Neogene ranges are, as yet, poorly known is another limiting factor. However, comparisons which are so far possible, are consistent with ages based on other fossil groups.

The standard planktonic foraminiferal zonation used for most other DSDP legs cannot be directly applied in the Norwegian-Greenland Sea. The mainly tropical species on which the standard zonation is based never lived in this high latitude area. Even zonal schemes recently established for the North Atlantic (Berggren, 1972; Poore and Berggren, 1975) do not apply except for the youngest part of the section. After a more detailed (SEM) study of the rare calcareous plankton, it may be justified to make a high latitude zonation (Van Hinte, this volume) which will consist of a few broad zones only.

The impossibility of using planktonic Foraminifera not only results from poverty of the original populations, but is also due to the fact that most sections cored were deposited below or near the carbonate compensation surface (CCS, Berger and Winterer, 1974), which, probably throughout the Tertiary, was exceptionally shallow in the area. Most plankton tests, of a low diversity to start with, were dissolved and have not been preserved. Apart from extremely rare Globorotalia spp. in the Pleistocene of the V $\phi$ ring Plateau, not one keeled planktonic test was found

Figure 1 gives a preliminary combined planktonic, calcareous benthonic and arenaceous benthonic foraminiferal zonal scheme. It obviously has a low resolution. However, the scheme is applicable over the entire area and allows for a broad age determination of most of the cores. The age of the zones is based on direct comparison with northwestern Europe and, where it was possible to check with other fossil groups, it proved to be reliable in time stratigraphic correlation. Detailed work on the Pleistocene is in progress and probably will result in a finer subdivision. The same may be true for the calcareous Eocene. The non- calcareous ooze facies does not have any potential for further subdivision unless results of biometric studies on the zonal species allow for some. A more detailed per hole zonation with the arenaceous faunas of the clastic sections ("flysch faunas") will be of interest to interpret depositional environment, but will not be very useful in correlation.

The zones marked with a (1) are local range zones defined by the range of their nominal species. The zones marked with a (2) are partial range zones defined as follows. The Neogloboquadrina pachyderma Zone is defined by the dominant occurrence of left-coiling $N$. pachyderma. The $N$. atlantica $(\mathrm{S})$ Zone is defined by the dominance of left-coiling $N$. atlantica in the planktonic fauna. The (S) and the (D) stand for sinistral and dextral, respectively. $N$. atlantica (D) has a substantial number of dextrally coiling specimens, but no systematic count has been made yet, and the boundary is not necessarily at $50 \%$. The Spirosigmoilinella sp. Zone is defined by the presence of Spirosigmoilinella sp. without Martinotiella communis and without Spiroplectammina spectabilis.

The base of $N$. pachyderma Zone is considered to be about 2.8 m.y. old. Unlike other participants of Leg 38, van Hinte is of the opinion that this coincides with the Plio-Pleistocene boundary, that is, with the base of the Calabrian stage as defined by Gignoux (1913). The "age of the Plio/Pleistocene boundary" was discussed in a report distributed among Leg 38 participants and is available upon request (van Hinte).

\section{PALEOOCEANOGRAPHIC EVENTS IN THE VARIOUS FOSSIL GROUPS}

Paleontological events have been observed for the various fossil groups and are listed in Figures 2-16 and summarized in Figure 17.

An abundance peak of the radiolarian Hexalonche sp.A (Bjфrklund, this volume) was observed in Samples 338-7, CC; $341-31-5,17-19 \mathrm{~cm}$; and 348-15-2, 30-32 $\mathrm{cm}$ and served to correlate all these horizons under the assumption that this peak occurred time congruent at the mentioned intervals in early late Miocene. A drastic floral assemblage change occurred at Site 348 below Sample $16-3,80 \mathrm{~cm}$, middle Miocene, with a mass occurrence of Stephanogonia horridus (Schrader, this volume), which is followed by a considerable increase of aberrant silicoflagellates just above (Martini and Muller, this volume).

Mass occurrences of Triceratium barbadense were observed in Samples 338-29, CC; 339-6-2, $60 \mathrm{~cm}$ to 3397-2, $70 \mathrm{~cm} ; 340-3, \mathrm{CC} ; 340-7, \mathrm{CC}$; and 8, CC, late Eocene. Again this served as a basis for correlation. An enrichment of large Archaeomonadaceae were found at Site 338, Core 27, late Eocene. High abundances of Phaeodarians were found in Samples 348-5, CC through 348-7, CC.

In the lower Eocene (approximately standard calcareous nannoplankton zones NP 11/12), the boreal nannoplankton species Imperiaster obscurus has been, quite commonly, found at Site 338 (V $\phi$ ring Plateau) and Site 343 (Lofoten Basin). It is also present in fair numbers in the central North Sea Basin and to the south in Denmark, Northern Germany, Belgium, and 


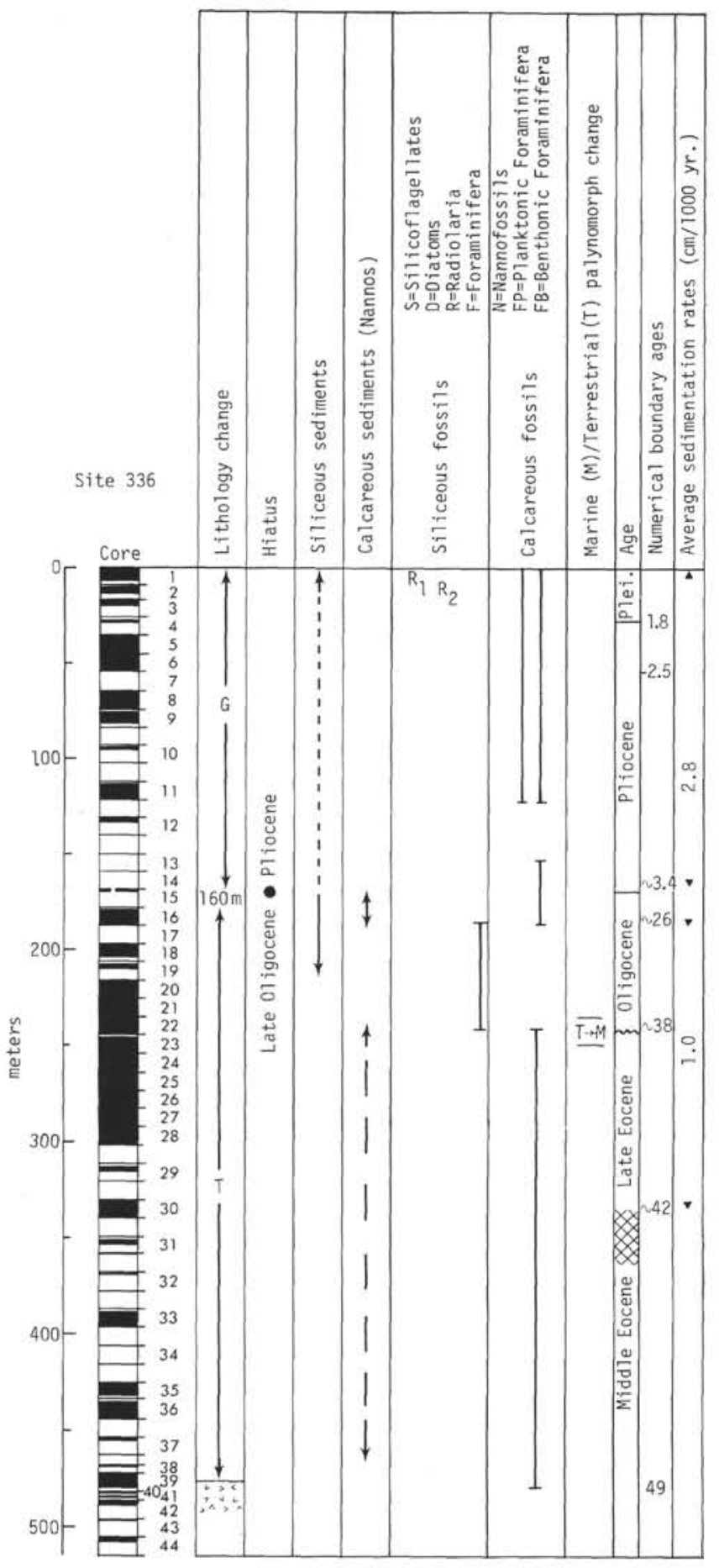

Figure 2. Site 336 summary figure with cored and recovered intervals, major lithologies, occurrence of hiatuses and/or unconformities with upper and lower age boundaries (occurrence of siliceous and calcareous sediments and microfossils, paleontological events within the siliceous microfossil realm and in the calcareous microfossil realm). Note: for siliceous and calcareous foraminiferal microfossils the total range of occurrences are plotted and not any paleontological event. The change within the marinedinoflagellate to terrestial spore and pollen ratio from $T$ to $M$ or from $M$ to $T$ follows. Ages are drawn from Fig. ure 1 as well as numerical ages in m.y. Finally, we have plotted average sedimentation rates for the indicated intervals.

England, to the southeast transported by a cold current via the Ural-Street down to the northern Caucasus (Martini, 1970, and unpublished data). However, it seems to be rare to the west at Site 117 on the Rockall Plateau (Bukry, 1972), and could not be found in the Bay of Biscay at Sites 118 and 119. The occurrence of this species seems to indicate a rather restricted water mass exchange between the Norwegian-Greenland Sea and the North Atlantic in early Eocene time.

The radiolarian species Arachnocalpis tumulosa was frequently found at Site 343 . This species has not been reported from the north Atlantic but from the west Siberian lowland (Kozlova and Gorbovets, 1966). Therefore, the radiolarian assemblage from the Norwegian Sea also points to a water exchange between the Norwegian Sea and the west Siberian lowland, most likely through the North Sea as suggested by nannofossils.

A remarkable abundance of Zygrhablithus bijugatus was noted (Müller, this volume) in the late Oligocene (nannoplankton zones NP 24 and NP 25) of Site 352 (Iceland-Faeroe Ridge), which was also noted at Sites 116 and 117 on the Rockall Plateau (Bukry, 1972; Perch-Nielsen, 1972) indicating shallow water or near-

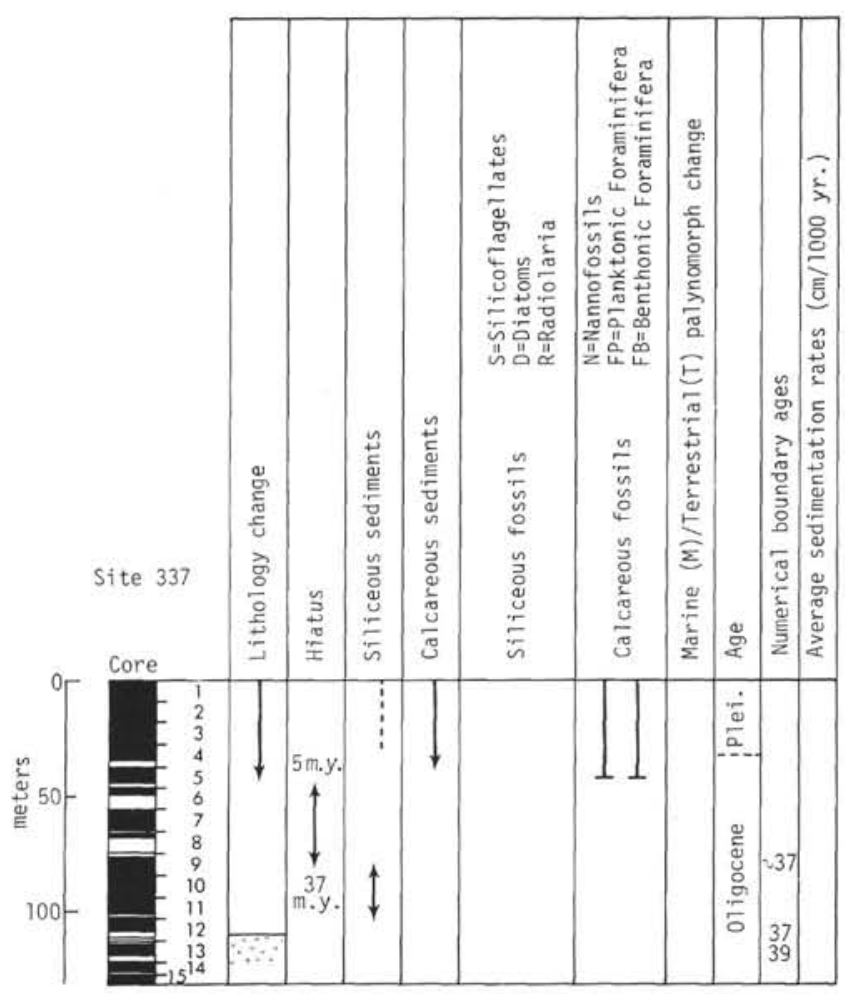

Figure 3. Site 337 summary figure with cored and recovered intervals, major lithologies, occurrence of hiatuses and/or unconformities with upper and lower age boundaries loccurrence of siliceous and calcareous sediments and microfossils, paleontological events within the siliceous microfossil realm and in the calcareous microfossil realm). See note Figure 2. 


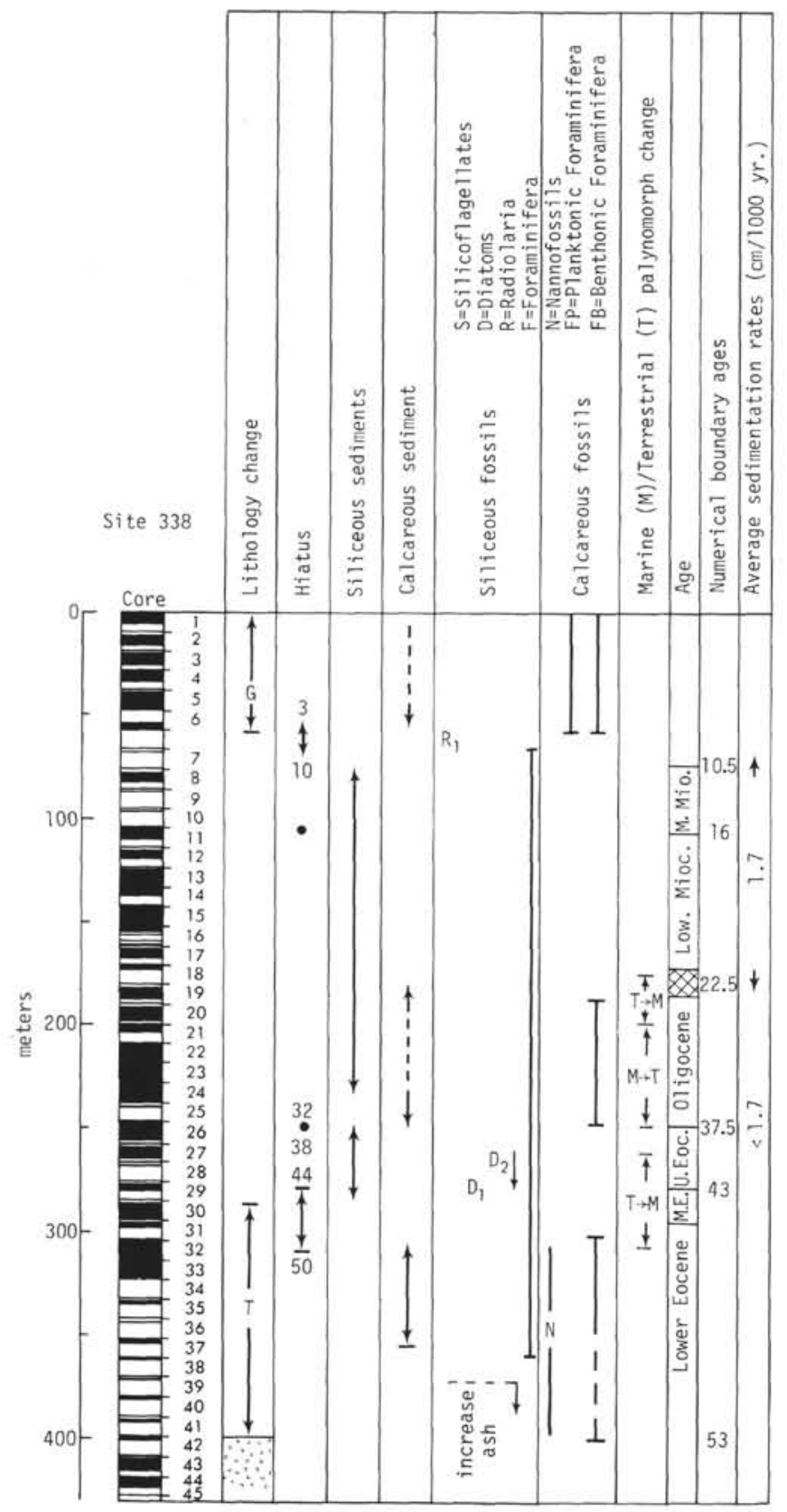

Figure 4. Site 338 summary figure with cored and recovered intervals, major lithologies, occurrence of hiatuses and/or unconformities with upper and lower age boundaries loccurrence of siliceous and calcareous sediments and microfossils, paleontological events within the siliceous microfossil realm and in the calcareous microfossil realm). See note Figure 2.

shore conditions at that time for both the Rockall Plateau and the Iceland-Faeroe Ridge. To the east of the Iceland-Faeroe Ridge at Site 336, Zygrhablithus bijugatus is rare throughout this interval.

In the early Miocene of Site 348 (Icelandic Plateau) Helicosphaera ampliaperta was noted in Cores 24 to 26 (Müller, this volume). This species is characteristic for assemblages in standard nannoplankton zones NN 3 and NN 4. It entered the North Sea Basin from the

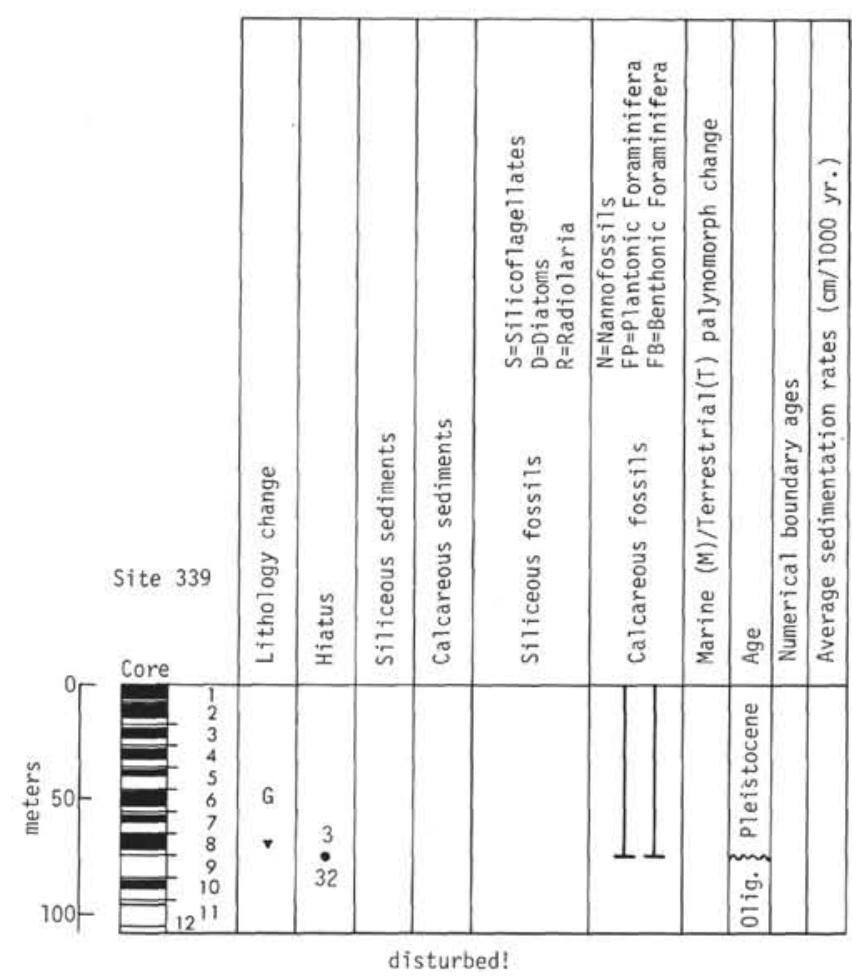

Figure 5. Site 339 summary figure with cored and recovered intervals, major lithologies, occurrence of hiatuses and/or unconformities with upper and lower age boundaries loccurrence of siliceous and calcareous sediments and microfossils, paleontological events within the siliceous microfossil realm and in the calcareous microfossil realm). See note Figure 2.

North Atlantic through the English Channel in Hemmoorian time (Martini, 1974). Its presence in the Icelandic Plateau area indicates once more a normal exchange of water masses between the North Sea and the Norwegian-Greenland Sea, and a somewhat restricted exchange between the Norwegian-Greenland Sea and the northeastern North Atlantic, as Helicosphaera ampliaperta obviously has not been found at Site 116 (Rockall Plateau), although several cores within the ranges of Sphenolithus heteromorphus and Helicosphaera ampliaperta have been recovered (PerchNielsen, 1972; Bukry, 1972). Whether this particular distribution is due to a current system or to a relatively high position of the Icelandic-Faeroe Ridge at that time is open for discussion.

Neogloboquadrina pachyderma shows an unusually wide range of morphologic variation in the upper cores (1-3) of the "glacial" section at Site 341. Specimens with a large hole in the ultimate chamber are common, the interval septa of these individuals are dissolved. Others have bulging, but undamaged, last chambers or a thin-walled bladder on its distal side. Still others have an attached smaller individual from such a bulge or from a "normal" last chamber. Abnormal penultimate chambers are less common but also do occur. Similar abnormal forms were found at the other V $\phi$ ring Plateau sites, but are rare. And indeed, the nature of the variation seems to indicate that $N$. pachyderma in this area 


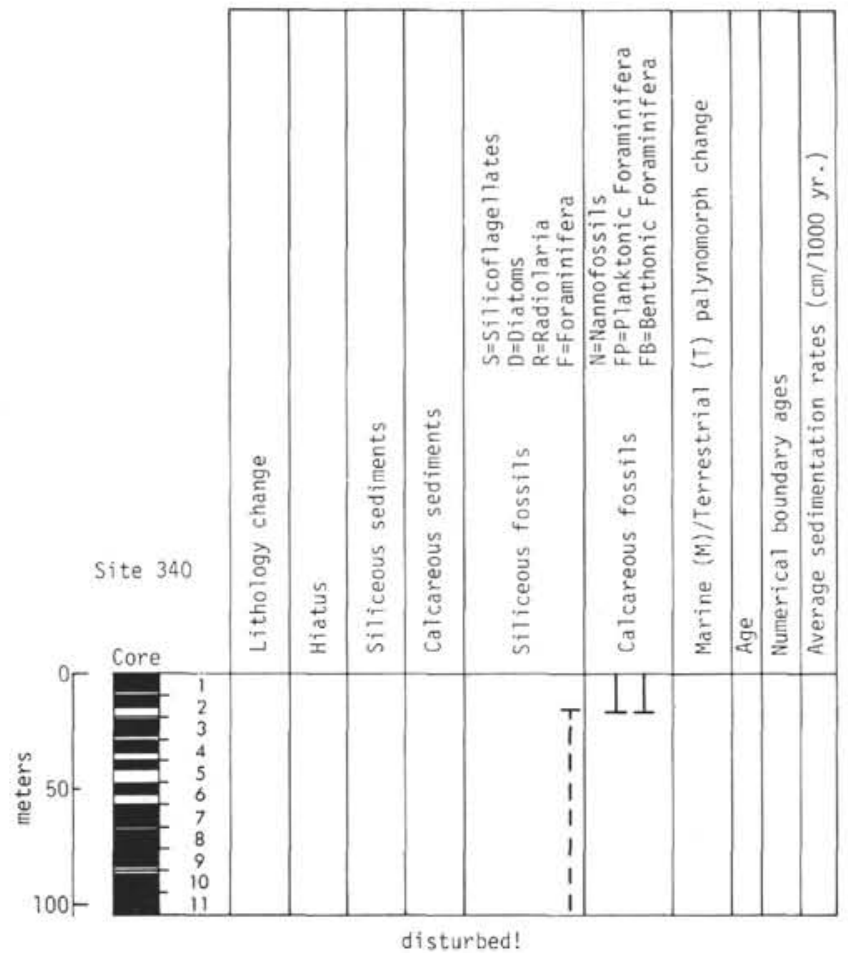

Figure 6. Site 340 summary figure with cored and recovered intervals, major lithologies, occurrence of hiatuses and/or unconformities with upper and lower age boundaries loccurrence of siliceous and calcareous sediments and microfossils, paleontological events within the siliceous microfossil realm and in the calcareous microfossil realm). See note Figure 2.

had peculiar abnormal growth and reproduction problems; chambers of aberrant form being developed and the offspring remaining attached to the parental test or leaving an interiorly dissolved parental test behind. It will be interesting to determine whether there are A, A2, or B generation individuals. As to possible environmental causes for the abnormal morphology, we could think of the influence of hydrocarbon leakage from nearby diapirs, or the effect of mixing two water masses: the cool Arctic and the warm Atlantic waters.

\section{SUBSIDENCE OF THE ICELAND-FAEROE RIDGE}

Continued submergence to the Oligocene is suggested at Site 336 by decrease of grain size in the sediments indicating deposition in deeper waters and by the ratio of planktonic/benthonic foraminifera. The latter indicated inner-middle neritic environment at 45 m.y., neritic at $37 \mathrm{~m} . \mathrm{y}$., and outer neritic to upper bathyal at 30 m.y.

We have, of course, no sedimentary record from the upper Oligocene to the vicinity of the Pleistocene at this site. Two alternative possibilities are suggested for the upper Oligocene-Pliocene hiatus at this site: (1) Sediment deposition stopped at the upper Oligocene and did not resume until the glaciation; or (2) Assume arbitrary amounts of sedimentation after Oligocene.

Further study of Site 336 cores is essential to indicate the climatic changes during the Quaternary. A very

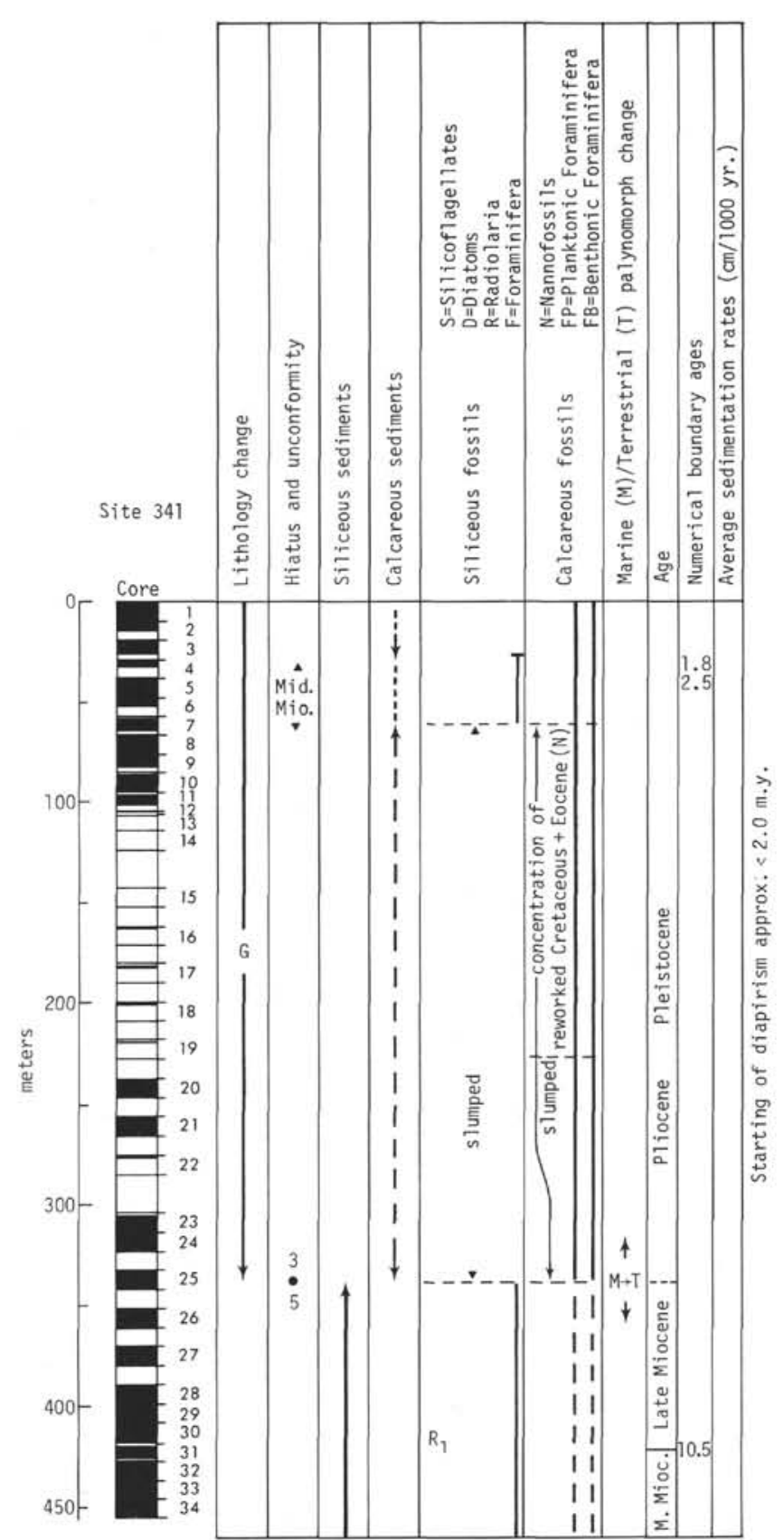

Figure 7. Site 341 summary figure with cored and recovered intervals, major lithologies, occurrence of hiatuses and/or unconformities with upper and lower age boundaries loccurrence of siliceous and calcareous sediments and microfossils, paleontological events within the siliceous microfossil realm and in the calcareous microfossil realm). See note, Figure 2.

preliminary study of core-catcher samples shows (see report on Radiolaria and History of Ice Rafting, this volume) that Cores $4,5,8,10$, and 11 may represent warm periods, while Cores 1 through $3,6,7,9,12$, and 13 may indicate cold periods. Because of the large sampling interval, no precise inferences concerning the number of climatic oscillations can be made, but it appears that with careful and detailed study of the 


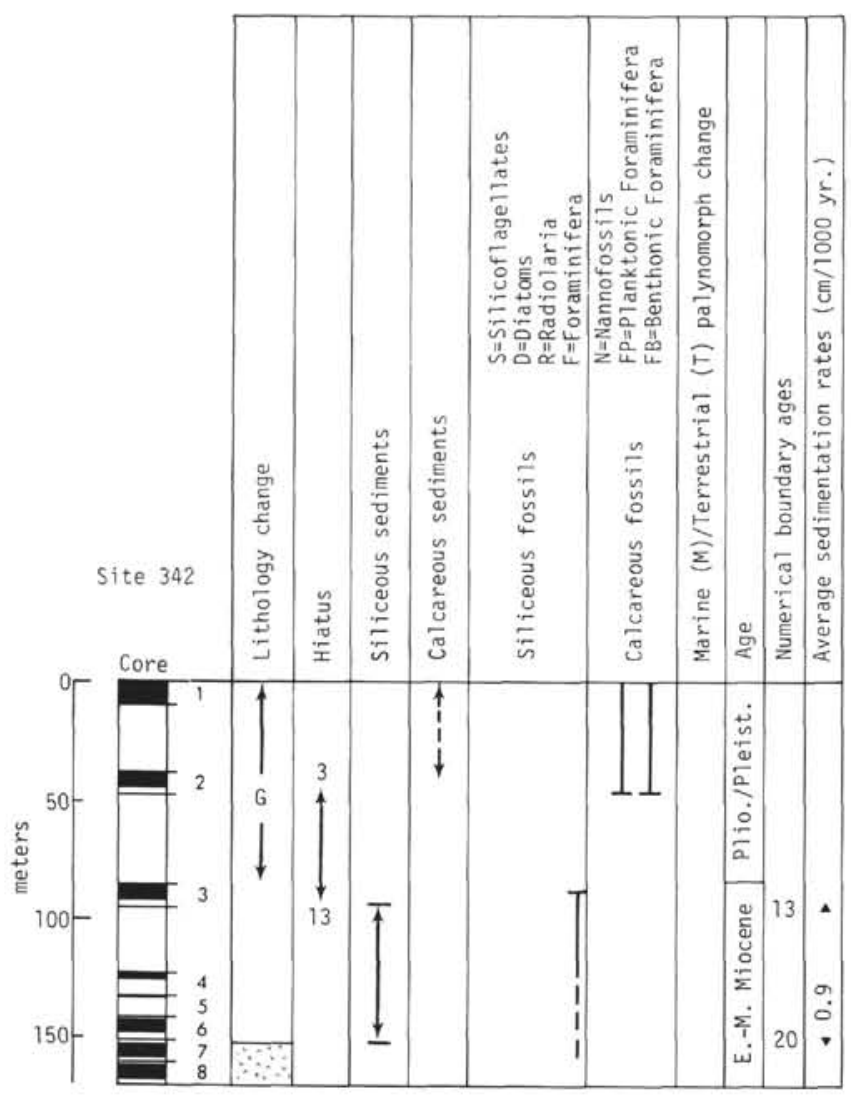

Figure 8. Site 342 summary figure with cored and recovered intervals, major lithologies, occurrence of hiatuses and/or unconformities with upper and lower age boundaires loccurrence of siliceous and calcareous sediments and microfossils, paleontological events within the siliceous microfossil realm and in the calcareous microfossil realm). See note, Figure 2.

material, much data might be forthcoming. This also applies for the calcareous nannoplankton.

We will attempt to interpret the information obtained from cores at Site 336 in terms of a model for the evolution of the Norwegian Sea via sea-floor spreading. In this model, the unusual elevation of the IcelandFaeroe Ridge may be interpreted as the trail of a "hot spot" in the mantle.

There is controversy about whether the Faeroes lie on continental crust, or whether they belong genetically to the oceanic Iceland-Faeroe Ridge. Site 336 lies far enough away from the Faeroes, so that regardless of the controversy about the Faeroes, this site can be safely assumed to be a normal part of the Iceland-Faeroe Ridge.

Preliminary shipboard analysis suggests that the basalt at this site may not be typical of the tholeiitic basalts formed typically in mid-ocean rifts. However, the range of basalts, in Iceland, for example, which also has an origin by sea-floor spreading in association with an underlying hot spot, is so large that it is not possible to rule out the formation of the basalt at Site 336 through extrusion involved in sea-floor spreading. This argument is, of course, invalid if Iceland was not created by sea-floor spreading.

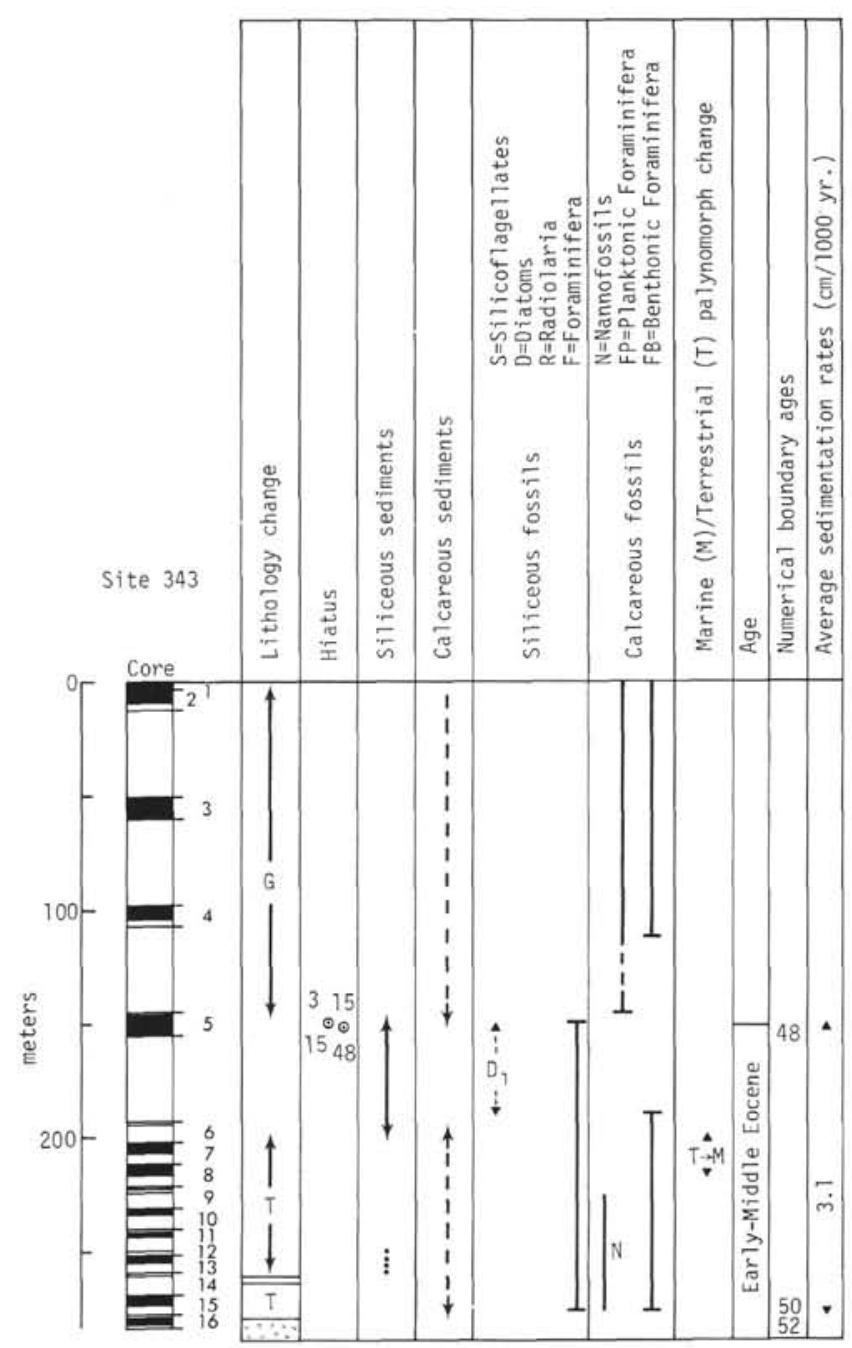

Figure 9. Site 343 summary figure with cored and recovered intervals, major lithologies, occurrence of hiatuses and/or unconformities with upper and lower age boundaries loccurrence of siliceous and calcareous sediments and microfossils, paleontological events within the siliceous microfossil realm and in the calcareous microfossil realm). See note, Figure 2.

At the present time, we have no direct evidence of the age of the basalt. The overlying rubble and sediments have been derived from the basalt by subaerial weathering, and the contact of these beds with the middle Eocene claystones was not observed. However, if we accept the subsidence history of this site which was discussed earlier, it suggests strongly that there is no major gap in time between the claystones, which were deposited in shallow waters, and the basalt. If this is accepted, the age of the basalt is also middle Eocene. This age does not conflict with that predicted under the sea-floor spreading model, since the Iceland-Faeroe Ridge was created during the time between the initiation of sea-floor spreading in the Norwegian Sea in the Paleocene (about 60 m.y.) and the birth of Iceland in the late Oligocene.

If at the time of its formation, Site 336 was at or near sea level, the highest point along the active axis of the 


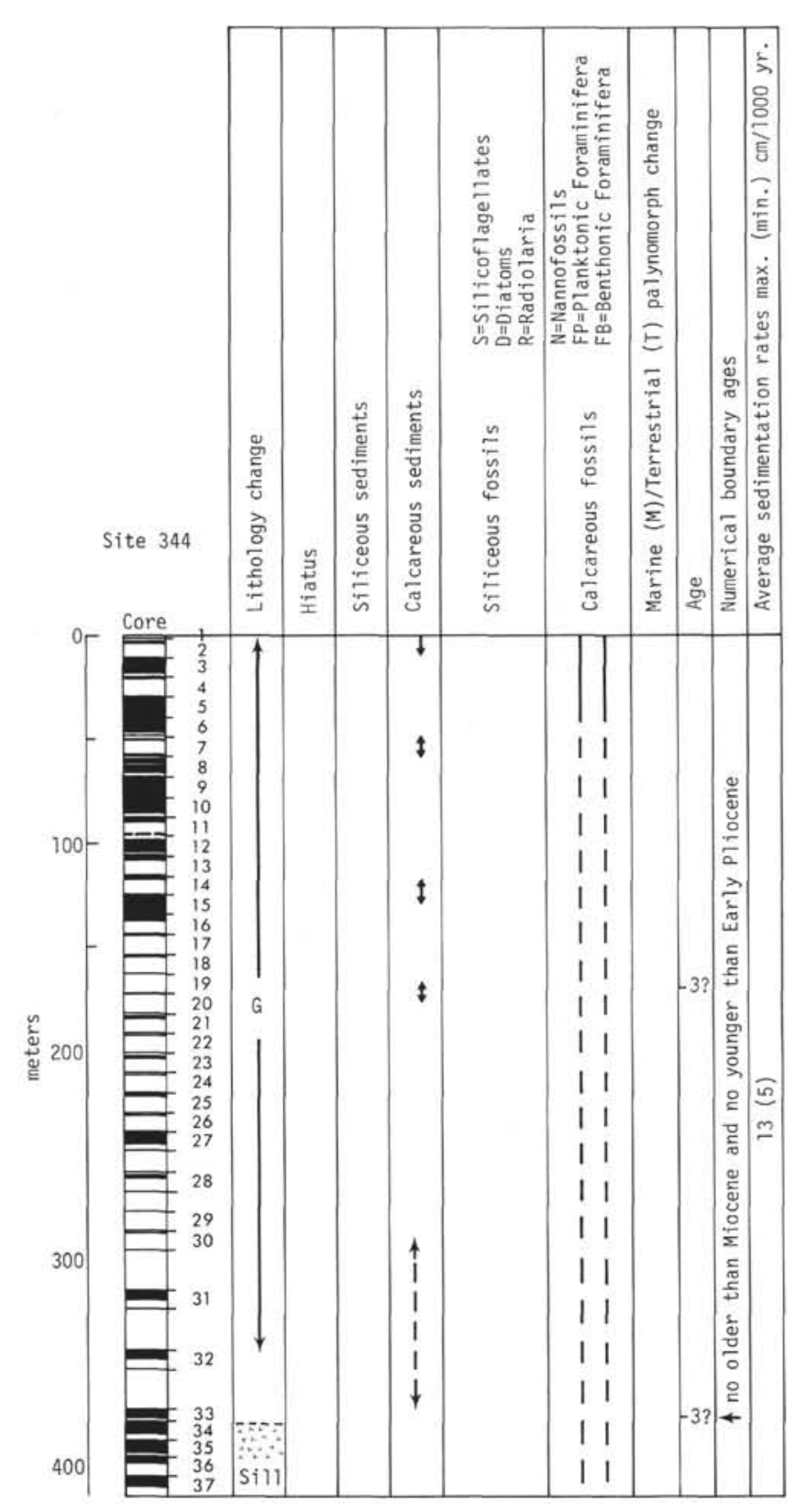

Figure 10. Site 344 summary figure with cored and recovered intervals, major lithologies, occurrence of hiatuses and/or unconformities with upper and lower age boundaries (occurrence of siliceous and calcareous sediments and microfossils, paleontological events within the siliceous microfossil realm and in the calcareous microfossil realm). See note, Figure 2.

Iceland-Faeroe Ridge (the spreading axis was presumably transverse to the strike of the ridge) was much higher. At the present time, the difference between basement elevation at Site 336 and at the top of the Iceland-Faeroe Ridge is about 950 meters. Ignoring erosion and subsidence due to loading, we can roughly postulate that this difference in the two elevations has been maintained. Thus, the initial elevation of the crest of the ridge at the spreading axis was about 950 meters. Inferring from our subsidence theory, it would take roughly $30 \mathrm{~m} . \mathrm{y}$. for the crest of the ridge to subside below sea level as it moved away from the spreading axis. These calculations use gross approximations and assumptions, and conclusions are, therefore, tentative. However, they seem to support the picture of a spreading ridge over a hot spot, where the highest elevation along the spreading axis is several hundred meters above sea level, and it takes tens of millions of years for the highest point to subside below sea level.

An important shift in the spreading axis occurred about 30 m.y. from the Norway Basin to the IcelandJan Mayen Ridge. It is quite possible that at the same time a shift occurred from the Iceland-Faeroe Ridge to Iceland. If this is so, we can think of the Iceland-Faeroe Ridge being formed in the interval 60 m.y. to 30 m.y. By the arguments suggested earlier, this ridge was emergent during this entire period, and only after the shift of the ridge axis did it begin to be submerged below sea level.

During this time the Norway Basin was closed off on three sides by the Jan Mayen Ridge (then attached to Greenland), Iceland-Faeroe Ridge, and continental margin of Norway. Therefore the northern flank of the Iceland-Faeroe Ridge had no connection with the North Atlantic. The disparity of the Oligocene foraminiferal fauna at Site 336 with typical North Atlantic fauna bears this out. As the Iceland-Faeroe Ridge submergence proceeded, the flow of water would have been increasingly responsible for nondeposition and erosion. We are not sure how much sediment was deposited in Miocene and Pliocene times at Site 336, but certainly current activity must have played an important role in preventing sediment to be deposited, and in possibly eroding older sediments.

\section{GLACIATION}

Major northern hemisphere glaciation was defined (Berggren, 1972c) to have been initiated approximately 3 m.y.B.P. Unfortunately, Leg 38 sites did not recover a complete sedimentary cover for this period of time except at Sites 341 and 348. How much, and if any, is missing of the "glacial" history by erosion at the other sites cannot be calculated. Site 336 sediments were used to calculate past fluctuations of the North AtlanticNorwegian Current paths and thus indications of glacial periods (Bj申rklund, this volume). About $65 \%$ and $58 \%$ of the total radiolarian fauna were observed to consist of Cycladophora davisiana in Samples 336-1-4, $40 \mathrm{~cm}$ and $336-2-1,92 \mathrm{~cm}$. This species follows, in other areas, directly the $\delta \mathrm{O}_{18}$ curve and may be used as a direct ice-cover paleodetector (Hays et al., in press). Intervals being interpreted as representing Interglacial periods at Site 366 demonstrate calcareous faunas and floras of even less diversity than these from the Norwegian Sea area (Kellogg, 1974).

Sedimentation rates for the "glacial" sequences at the sites north of Iceland (Site 348) is a maximum of 3.7 , a minimum of $1.0 \mathrm{~cm} / 1000 \mathrm{yr}$, and approximately $2.0 \mathrm{~cm} / 1000 \mathrm{yr}$ at Site 338 on the V $\phi$ ring Plateau. Further studies of cores from Site 336 is essential to indicate climatic changes during the Quaternary. A total of 89 samples was studied from the "glacial" sequence 


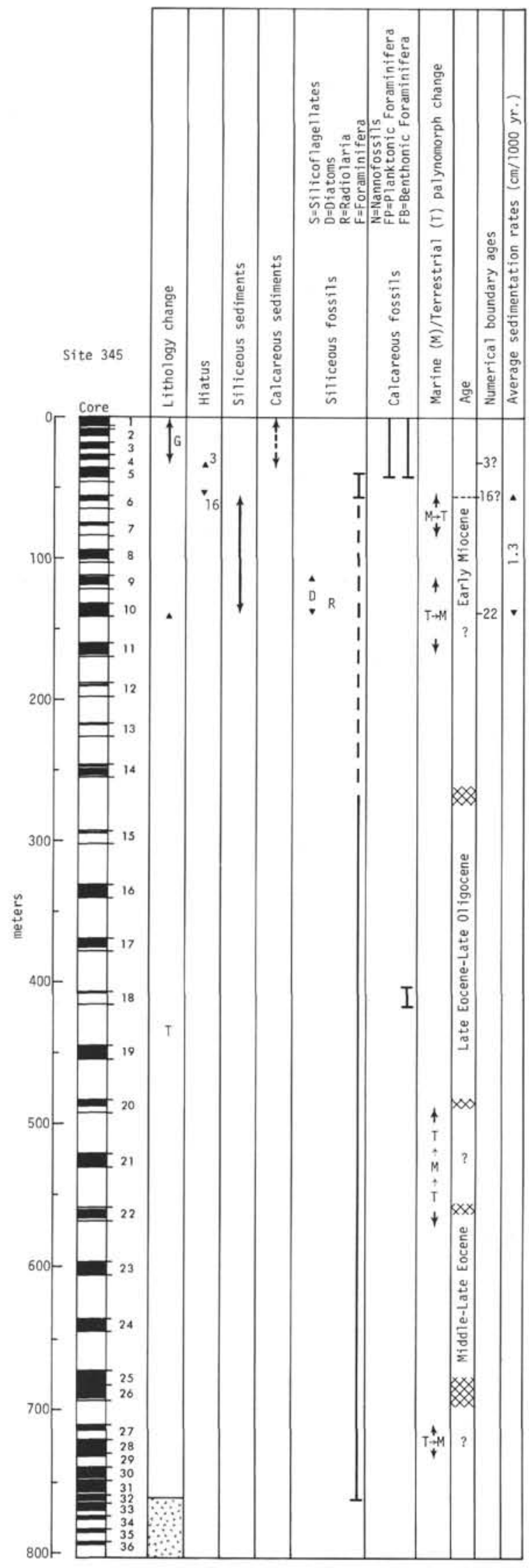

Figure 11. Site 345 summary figure with cored and recovered intervals, major lithologies, occurrence of hiatuses and/or unconformities with upper and lower age boundaries loccurrence of siliceous and calcareous sediments and microfossils, paleontological events within the siliceous microfossil realm and in the calcareous microfossil realm). See note, Figure 2.

at Site 336 for their radiolarian content (Bjфrklund, this volume). Unequally spaced sampling intervals and a noncontinuous sequence did not permit presenting a continuous glacial history. However, if the presence and absence of radiolarians and diatoms reflect climatic oscillations, 35 climatic shifts were detected from the samples. Warmer intervals are found between Samples $1-2,35 \mathrm{~cm}$ to $1-4,40 \mathrm{~cm} ; 2-1,92 \mathrm{~cm}$ to $2-2,20 \mathrm{~cm} ; 3-1$, $138 \mathrm{~cm}$ to $3-2,61 \mathrm{~cm} ; 4-2,84 \mathrm{~cm}$ to $4, \mathrm{CC} ; 5-5,70 \mathrm{~cm}$ to $5-5,125 \mathrm{~cm} ; 5-6,130 \mathrm{~cm}$ to $5, \mathrm{CC} ; 6-1,40 \mathrm{~cm}$ to $6-2,145$ $\mathrm{cm} ; 6-4,145 \mathrm{~cm}$ to $6-5,25 \mathrm{~cm} ; 8-1,25 \mathrm{~cm} ; 8-2,35 \mathrm{~cm} ; 8-$ $4,25 \mathrm{~cm}$ to $8-6,20 \mathrm{~cm} ; 8, \mathrm{CC}$ to $9-1,125 \mathrm{~cm} ; 9-2,75 \mathrm{~cm}$ to $9-3,75 \mathrm{~cm} ; 9-4,120 \mathrm{~cm} ; 10-1,75 \mathrm{~cm} ; 10-2,32 \mathrm{~cm} ; 10$, $\mathrm{CC}$ to $11-3,110 \mathrm{~cm}$; and $11, \mathrm{CC}$.

\section{INITIATION OF NORWEGIAN SEA OVERFLOW WATER}

The bottom water of the North Atlantic basin currently forms in the Norwegian Sea as warm saline Norwegian current water cools and becomes more dense by evaporation. This dense water overflows the

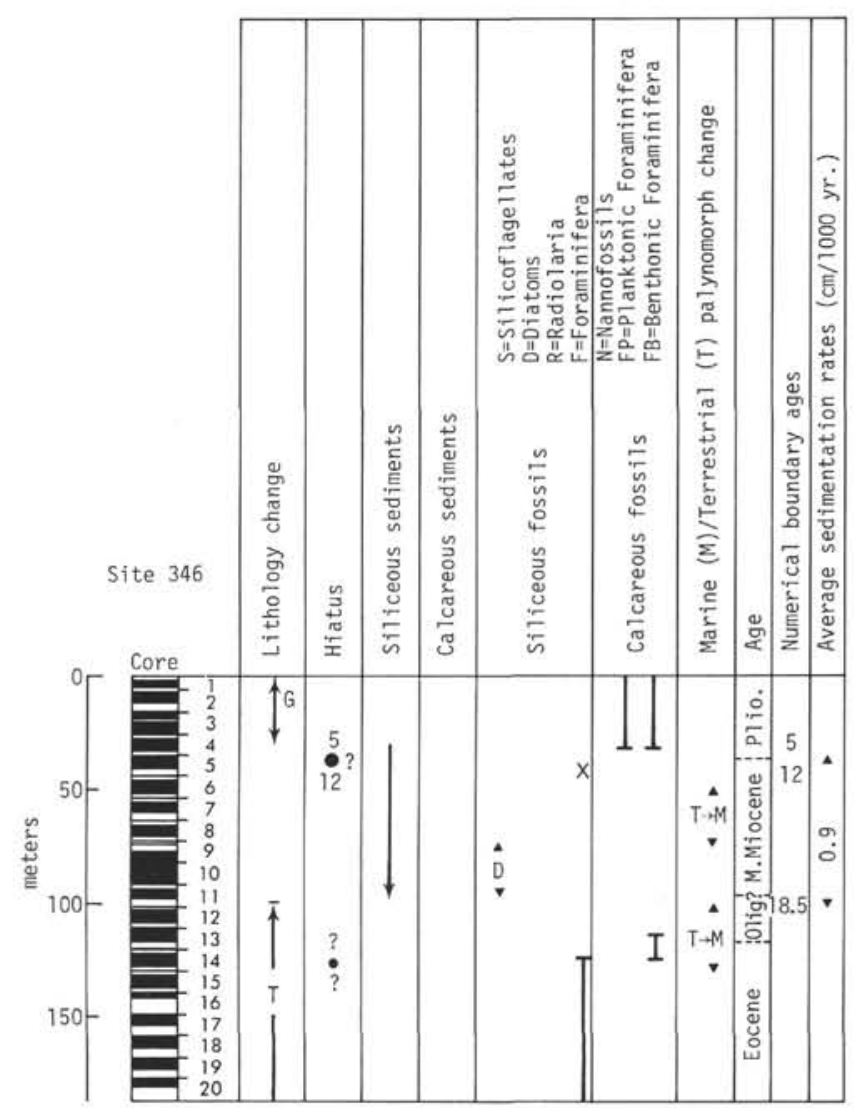

Figure 12. Site 346 summary figure with cored and recovered intervals, major lithologies, occurrence of hiatuses and/or unconformities with upper and lower age boundaries loccurrence of siliceous and calcareous sediments and microfossils, paleontological events within the siliceous microfossil realm and in the calcareous microfossil realm). See note, Figure 2. 


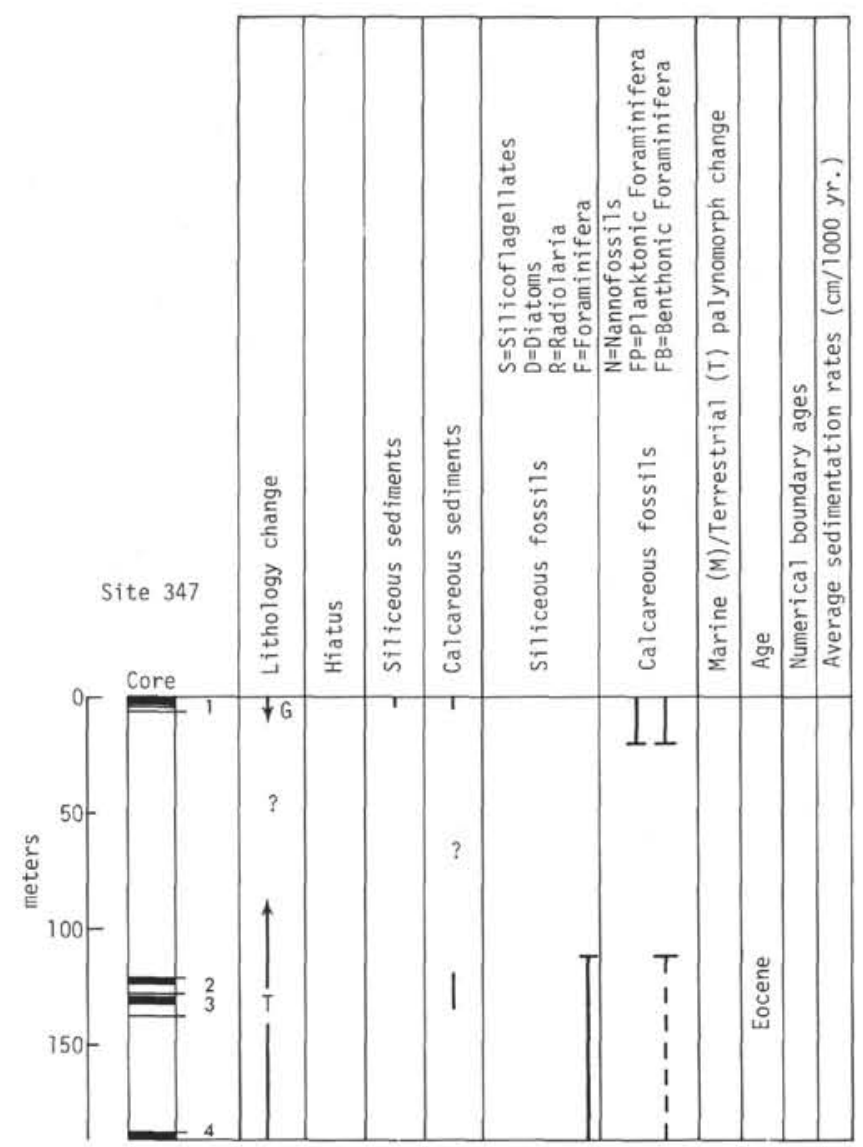

Figure 13. Site 347 summary figure with cored and recovered intervals, major lithologies, occurrence of hiatuses and/or unconformities with upper and lower age boundaries loccurrence of siliceous and calcareous sediments and microfossils, paleontological events within the siliceous microfossil realm and in the calcareous microfossil realm). See note, Figure 2.

Denmark Strait and the Iceland-Faeroe Ridge to form lower North Atlantic deep water or Norwegian Sea overflow water (Worthington, 1970). Variations in bottom water production could be reflected in the sedimentary history, and only could be initiated by the influence of the North Atlantic-Norwegian Sea Current. This mechanism was controlled primarily by the subsidence of the Iceland-Faeroe Ridge which was at a depth level to allow a considerable water mass exchange between the North Atlantic and Norwegian Sea only at the end of the Miocene (van Hinte, preliminary data). Unconformities and hiatuses were observed (see Figure 17) at almost all sites between the overlying "glacial" sediments and the underlying biogenic siliceous sediments. The base of the Glacial sequences was calculated using Berggren's (1972b) data at 3 m.y. Sites on the Iceland Plateau should thus not be as intensively disturbed by bottom current than those more easterly sites (compare Figure 17). Some data on the first connection between the North Atlantic and Norwegian Sea water masses are believed to be gained from the radiolarians.

The species Velicucullus oddgurneri is found to occur for the first time in Samples 116-18, CC; 336-17, CC,

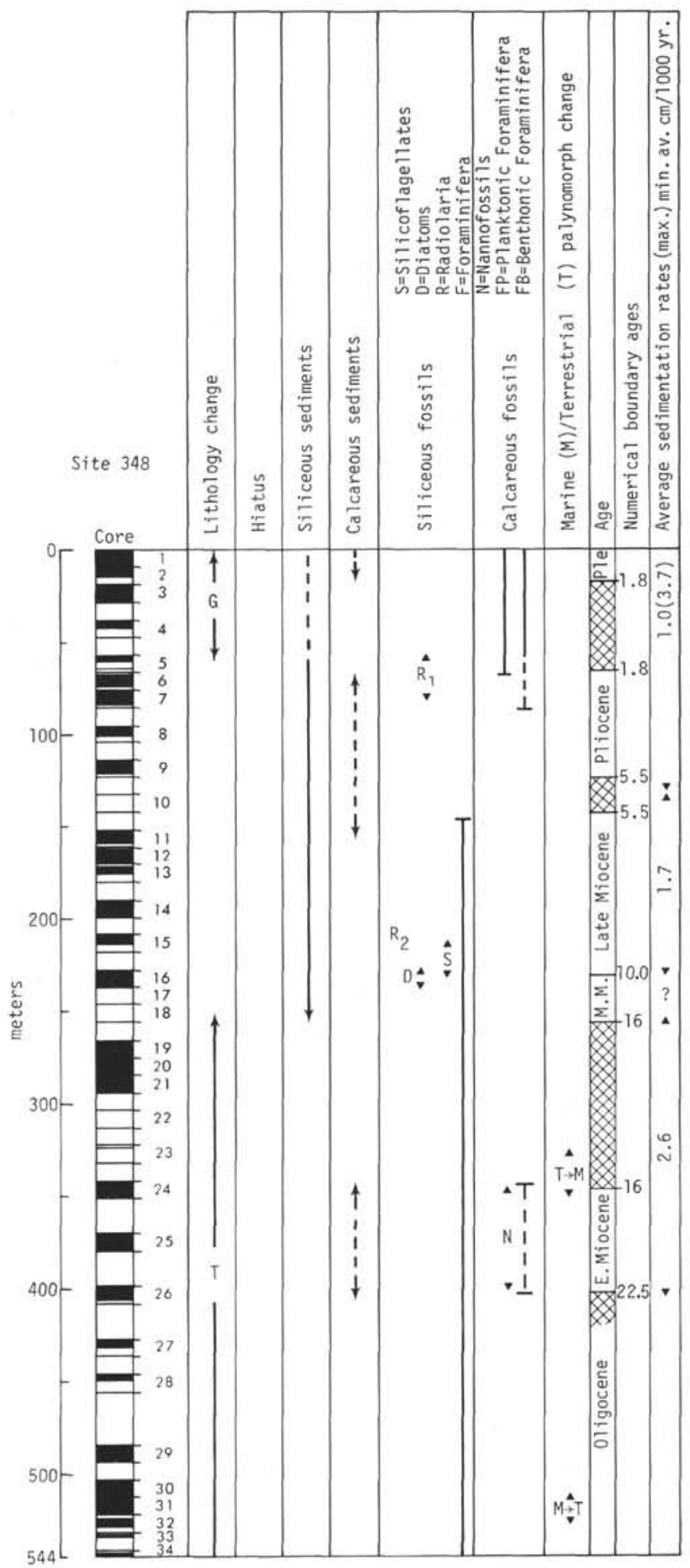

Figure 14. Site 348 summary figure with cored and recovered intervals, major lithologies, occurrence of hiatuses and/or unconformities with upper and lower age boundaries loccurrence of siliceous and calcareous sediments and microfossils, paleontological events within the siliceous microfossil realm and in the calcareous microfossil realm). See note, Figure 2.

and $338-19-3,80-82 \mathrm{~cm}$, being within the Naviculopsis lata Zone, which stratigraphically includes the late 


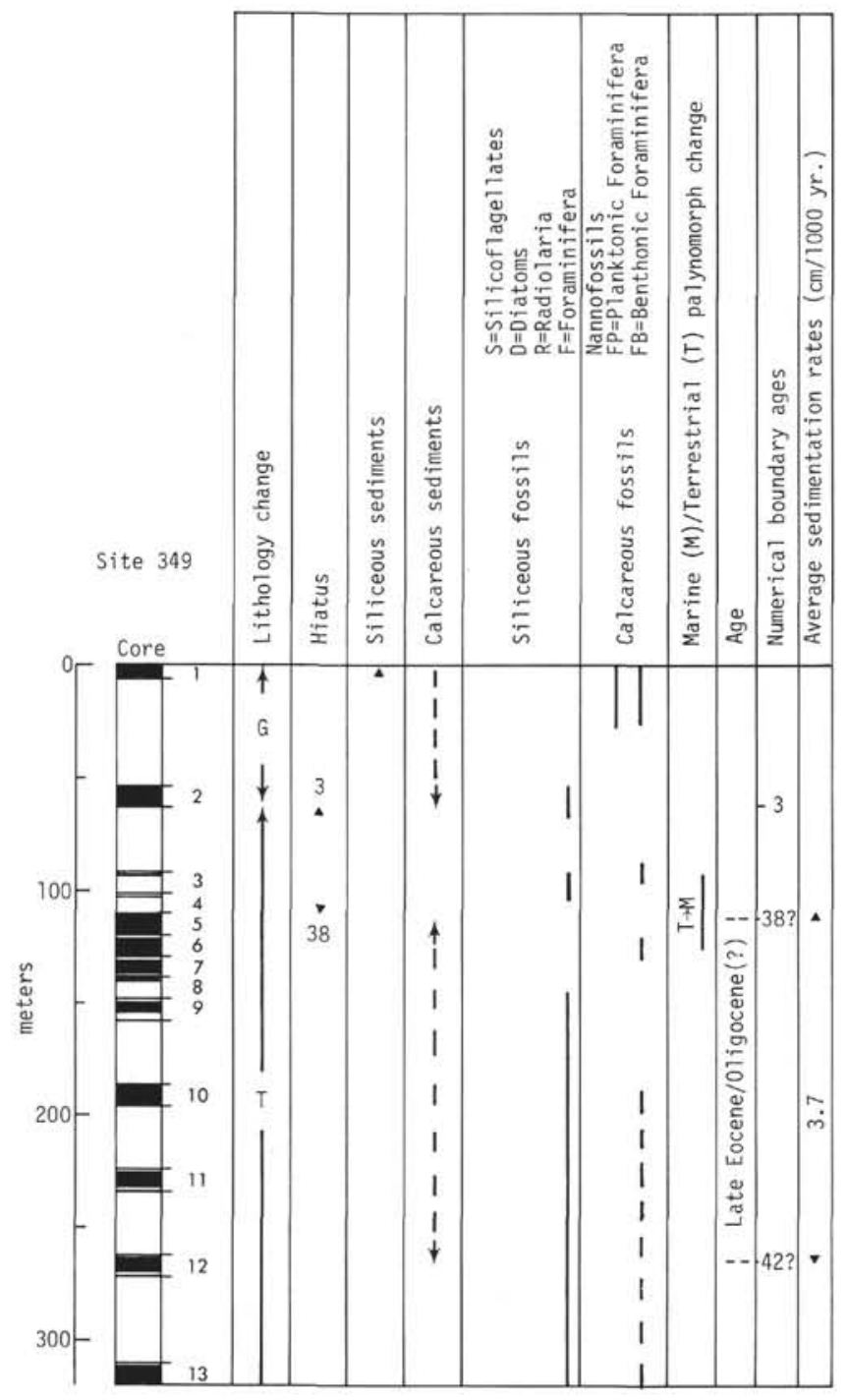

Figure 15. Site 349 summary figure with cored and recovered intervals, major lithologies, occurrence of hiatuses and/or unconformities with upper and lower age boundaries (occurrence of siliceous and calcareous sediments and microfossils, paleontological events within the siliceous microfossil realm and in the calcareous microfossil realm). See note, Figure 2.

Oligocene and lowermost early Miocene. $V$. oddgurneri is never common in North Atlantic sediments, but is quite abundant in certain intervals in Norwegian Sea sediments. This is interpreted as a result of better ecological conditions, as $V$. oddgurneri was transported from the North Atlantic into the Norwegian Sea.

Typical low latitude radiolarians are practically absent from Norwegian Sea sediments. However, Cyrtocapsella tetrapera was first found in Sample 338-17, $\mathrm{CC}$, dated by the silicoflagellates to the upper part of the $N$. lata Zone. C. tetrapera at Site 116, in early Miocene sediments, was reported by Benson (1972) to be common to abundant. This is taken as evidence for a definite connection of the North Atlantic and Norwegian Sea in lower-middle early Miocene. In other

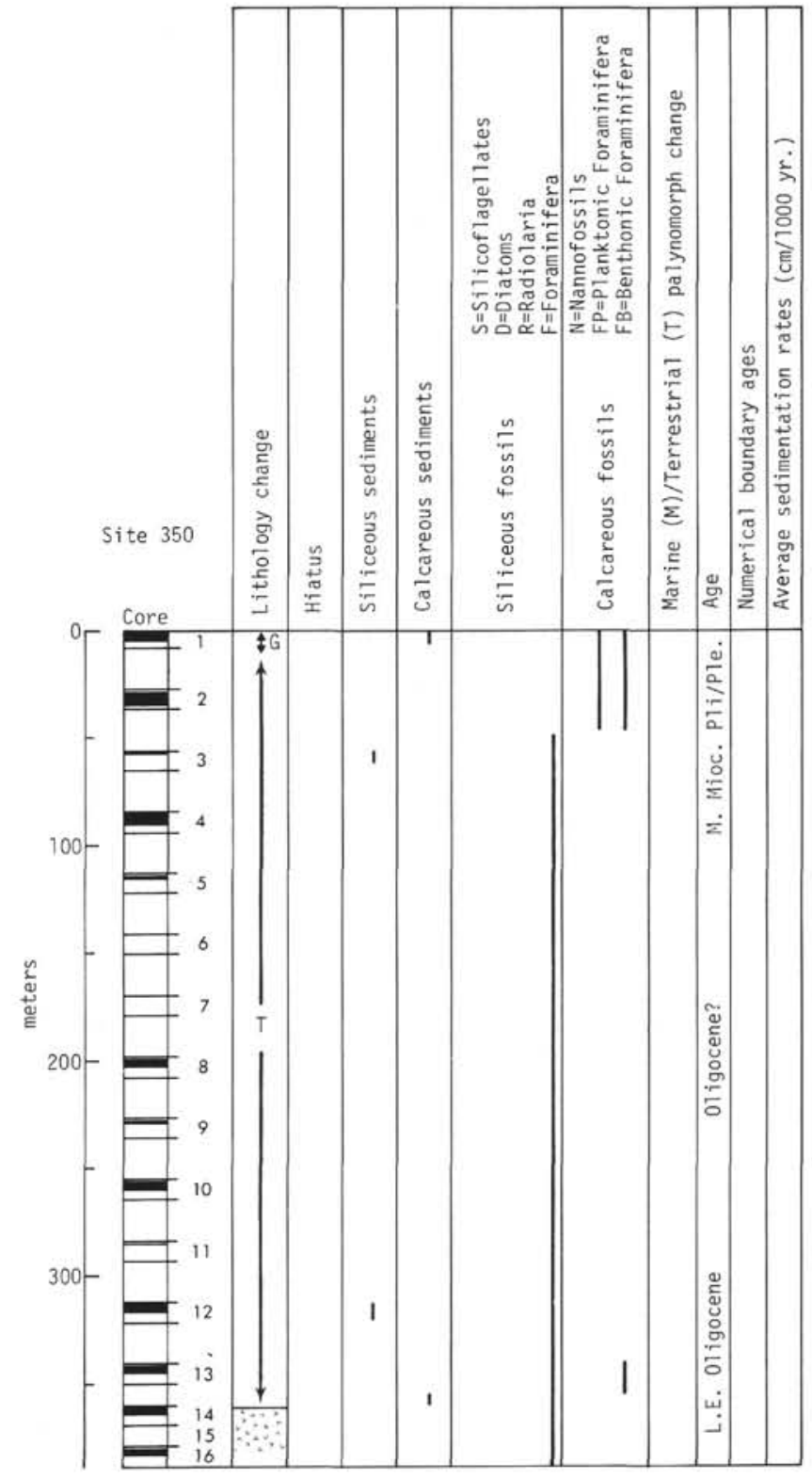

Figure 16. Site 350 summary figure with cored and recovered intervals, major lithologies, occurrence of hiatuses and/or unconformities with upper and lower age boundaries loccurrence of siliceous and calcareous sediments and microfossils, paleontological events within the siliceous microfossil realm and in the calcareous microfossil realm). See note, Figure 2.

words, water exchange between the two oceans was possible earliest at about 29 m.y. ( $V$. oddgurneri), but definite at about $21 \mathrm{~m} . \mathrm{y}$. (C. tetrapera) according to radiolarians.

\section{PLATE TECTONIC EVENTS}

Talwani and Eldholm (in press) have reported and summarized the geological history of the GreenlandNorwegian Sea, and have concluded from both seismic and magnetic measurements the following tectonic events. These, on the other hand, should be reflected in both sedimentological and paleontological parameters. 


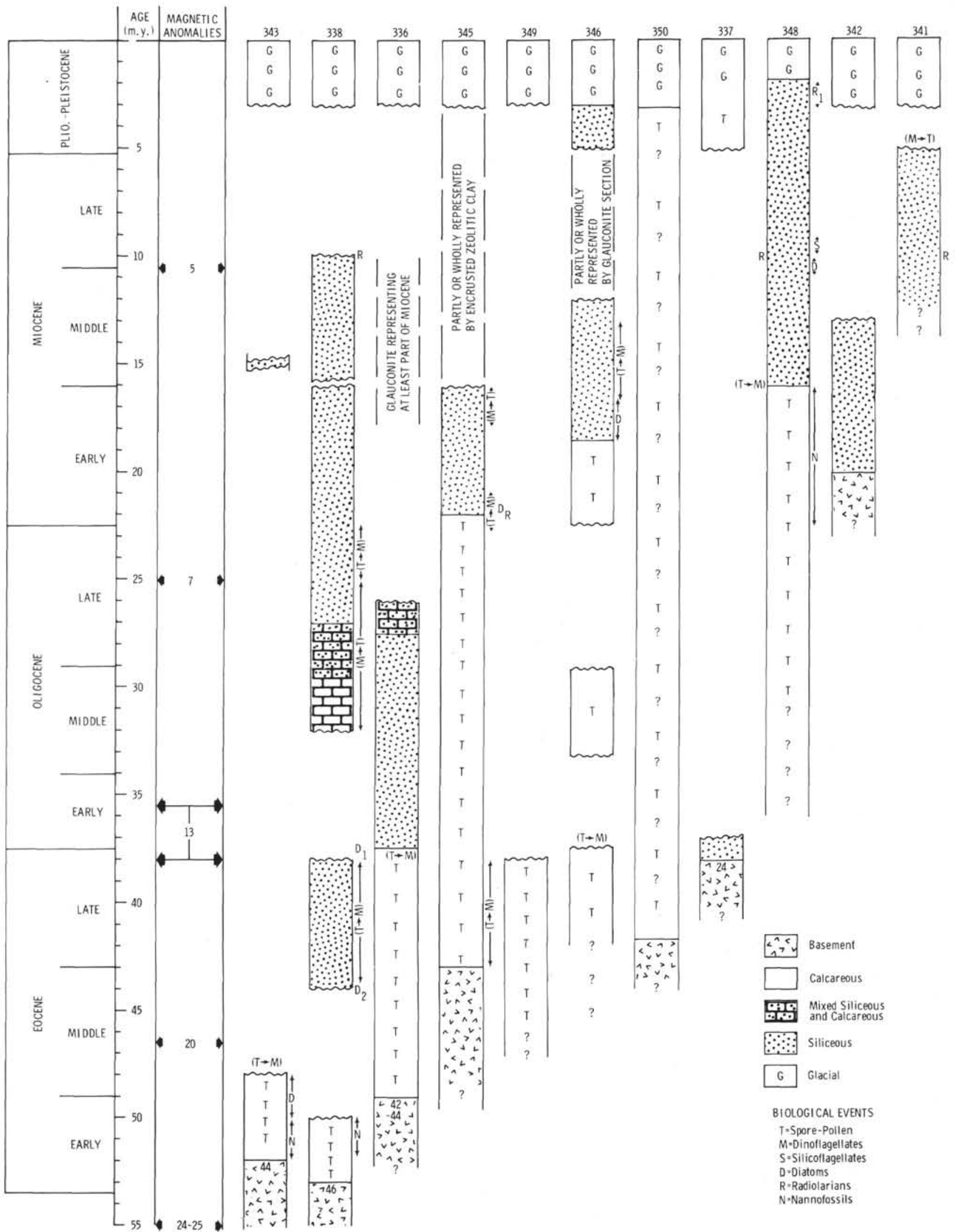

Figure 17. Summary figure with major lithologies, paleontological events, accumulation of hiatuses and unconformities, and age of basement-sill (ages within the basement signature are K/Ar dates). Sites are oriented on the basis of ascending age of basement. Sites 344, 339, and 347 are omitted from this figure due to poor recovery and poor micropaleontological data. 
In Figure 17, we have drawn most of the Leg 38 sites to the absolute time scale as has been achieved by microfossil zonation. Included in this figure are major lithologies and microfossil events for Radiolaria, calcareous nannoplankton, silicoflagellates, diatoms, spores/pollen, and dinoflagellates. Events are defined on the basis of mass occurrences, of faunal and floral changes, of highly variable assemblages, of changes within the dinoflagellate to spore and pollen ratio expressed as $\mathrm{T}$ to $\mathrm{M}$, change from terrigenous input to marine input, and vice versa. The ranges of foraminifera represent total occurrences and should not be considered to represent biological events. We have also included in the basement-signature the available $\mathrm{K} / \mathrm{Ar}$ dates (Kharin et al., this volume).

1) The opening of the Norwegian-Greenland Sea started at about magnetic anomaly 24 to 25 time, which on the Heirtzler time scale is dated as 60-63 m.y.; this age, on the other hand, is and has been subject to revision and we have used a date of about 55 m.y. (PremoliSilva, personal communication) which, on the other hand, fits well with our findings. The oldest marine microfossil-bearing sediment at Sites 343 and 338 belongs to nannoplankton zone NP 12 , which is definitely of early Eocene age. Anomaly 24 is found in the Norwegian Sea, but anomaly 25 is not. Sediments are mainly terrigenous, but siliceous and calcareous microfossils are present. At this time Norway and Greenland broke apart at the Jan Mayen Fracture Zone. Nannoplankton and diatom assemblages indicate a restricted connection between the NorwegianGreenland Sea and the North Atlantic Ocean (compare discussion on Imperiaster obscurus) The radiolarian fauna recovered from Site 343 have species in common with early Eocene radiolarian faunas described from western Siberian lowland sections, supporting a connection between the Norway Basin and the Arctic Ocean via the North Sea Basin and further to the East.

2) From the time of early opening to approximately magnetic anomaly 20 , the connection between the Norwegian-Greenland Sea was advanced to form one ocean. Magnetic anomaly 20 is dated on the Sclater et al. (1974) time scale as 46.5 m.y. The manifestation of this connection is demonstrated by the hiatus at Sites 343 and 338 , and in a change from predominantly terrigenous sediments to biogenic siliceous sediments at Site 338 .

3) From the time of connection between the Greenland-Norwegian Sea to about anomaly 13 time, the Labrador Sea was also opening and the motion of Greenland was northwest to Eurasia. This is evidenced in a greater opening of the Norwegian Sea, while Greenland slid past the Barents Shelf and Svalbard. Thus, the Greenland Sea did not open until after magnetic anomaly 13 time ( 38 m.y.). Thus, a limited connection between this basin and the Arctic Ocean did not exist and was blocked by a land connection between Greenland and Svalbard. Calcareous and siliceous faunas and floras do show great similarities with those found of the same age along the Caucasus mountains. There was a connection between the Norwegian Sea through the Viking Graben (Talwani and Eldholm, in press, fig. 17) to the North Sea Basin and further east.
During the most part of the Oligocene, the diatom assemblages are partly of endemic character and can hardly be correlated to any other floras outside this area. The high abundance of marine benthonic species accounts for a rather restricted and partly shallow basin with abundant littoral and sublittoral diatoms blooming along its margins.

4) Since anomaly 13 time (approximately 38 m.y.), the opening of the Norwegian-Greenland Sea can be described by the separation of the Eurasian and North American plates. During this motion Greenland moved in a nearly westerly direction with respect to Norway. The northern part of the Knipovich Ridge axis has probably migrated eastward since its inception at about anomaly 13 time. Magnetic anomaly 13 time has been dated as being 36 m.y. on the Heirtzler time scale and 38 m.y. on the Sclater et al. (1974) time scale. Our data support the latter date. This was the time at which the first direct connection between the Arctic Ocean and the Norwegian-Greenland Sea was established along the Knipovich Ridge. This inflow of Arctic water caused the hiatus at Sites 338 and 346, and may be responsible for the pure calcareous ooze at Site 338. The same type of pure calcareous ooze is also found in the Pacific (Kulm, personal communication) and may mark a change in sea level at early Oligocene time (van Andel, personal communication) associated with a lowered CCS. Again, a drop of sea level can provide a higher input of marine benthonic diatom species into pelagic biogenic siliceous sediments. The event can also be indicated by the spore and pollen/dinocyst ratio from terrigenous to marine at Site 345 and by the absence of any planktonic foraminifera at Site 345, Core 18 .

5) Since anomaly 23 time, the opening has been along the Mohns and Reykjanes ridges. After the opening there was a probable shift in the axis at anomaly 23 time to the "Extinct Axis" in the Norway basin. The "Extinct Axis" was active until about anomaly 7 time. Subsequent to anomaly 7 time, the axis jumped west separating the Jan Mayen Ridge from Greenland. This new axis of spreading jumped again before anomaly 5 time to generate the presently active Iceland-Jan Mayen Ridge. Magnetic anomaly 7 is dated after Blakeley (1974) to be $25 \mathrm{~m} . \mathrm{y}$. and anomaly 5 to be $10 \mathrm{~m} . \mathrm{y}$. The various shifts of the spreading axis are also documented in the various sites by changes in the sediment nat 1 re from terrigenous to pelagic and by various biological events (compare Figure 17).

\section{ACKNOWLEDGMENTS}

We thank S. White and M. Talwani for providing us with unpublished manuscripts and steady interest for organizing a partly privately funded paleontological meeting in February in Kiel. H. Lacroix helped with drafting and Frau Schmidtmann with typing.

This paper is partly supported by the Deutsche Forschungsgemeinschaft (to E. Martini and H.-J. Schrader), the Norwegian Council for Science and Humanities (Bj申rklund Grant D41-31-19), and the National Science Foundation of America.

\section{REFERENCES}

Benson, R.N., 1972. Radiolaria, Leg 12, Deep Sea Drilling Project. In Laughton, A.S., Berggren, W.A., et al., Initial 
Reports of the Deep Sea Drilling Project, Volume 12: Washington (U.S. Government Printing Office), p. 10851113.

Berger, W.H. and Winterer, E.L., 1974. Plate stratigraphy and the fluctuating carbonate line: Spec. Publ. Int. Assoc. Sediment, no. 1, p. 11-48.

Berggren, W.A., 1972a. A Cenozoic time scale-some implications for regional geology and paleobiogeography: Lethaia, v. 5, p. 195-215. , 1972b. Cenozoic biostratigraphy and paleobiogeography of the North Atlantic: In Laughton, A.S., Berggren, W.A., et al., Initial Reports of the Deep Sea Drilling Project, Volume 12: Washington (U.S. Government Printing Office), p. 965-1001.

1972c. Late Pliocene-Pleistocene glaciation. In Laughton, A.S., Berggren, W.A., et al., Initial Reports of the Deep Sea Drilling Project, Volume 12: Washington (U.S. Government Printing Office), p. 953-963.

Berggren, W.A. and van Couvering, J.A., 1974. The Late Neogene: biostratigraphy, geochronology and paleoclimatology of the last 15-million years in marine and continental-sequences: Pal., Pal., Pla., v. 16, p. 1-216.

Blakeley, R.J., 1974. Geomagnetic reversals and crustal spreading rate during the Miocene: J. Geophys. Res., v. 79 , p. $2979-2986$.

Bukry, D., 1972. Further comments on coccolith stratigraphy, Leg 12, Deep Sea Drilling Project. In Laughton, A.S., Berggren, W.A., et al., Initial Reports of the Deep Sea Drilling Project, Volume 12: Washington (U.S. Government Printing Office), p. 1971-2083.

Gigmoux, M., 1913. Les formations marines pliocenes et quaternaires de l'Italie du Sud et de la Sicile: Ann. Univ. Lyon, N.S., No. 1, fasc. 36, 693 p.

Hays, J.D., Lozano, J., Shackleton, N.J., and Irwing, G., in press. An 18.000 BP reconstruction of Atlantic and western Indian Ocean sectors of the Antarctic Ocean: In Cline, R.M. and Jays, J.D. (Eds.), Geol. Soc. Am., Mem 145.

Kellogg, T.B., 1974. Late Quaternary climatic changes in the Norwegian and Greenland seas: Climate of the Arctic, p. 3-36.

Koizumi, J., 1973. The late Cenozoic diatoms of Sites 183193, Leg 19 Deep Sea Drilling Project. In Creager, J.S., Scholl, D.W., et al., Initial Reports of the Deep Sea Drilling Project, Volume 19: Washington (U.S. Government Printing Office), p. 805-854.
1975. Neogene diatoms from the western margin of the Pacific Ocean, Leg 31 DSDP. In Karig, D.E., Ingle, J.C., et al., Initial Reports of the Deep Sea Drilling Project, Volume 31: Washington (U.S. Government Printing Office), p. 779-819.

Kozlova, G.E. and Gorbovets, A.N., 1966. Radiolarii verkhnemelovykh i verkhne-eozenovykh otlozhenii ZapadnoSibirskoi nizmennosti, nedra. Vses. Neft. Nauchno-issled. Geol.-Razu Inst. No. 248, p. 159.

Martini, E., 1970. Imperiaster n.g. aus dem europäischen Unter-Eozän (Nannoplankton, incertae sedis.): Senckenberg. Lethaea, v. 51, p. 383-386.

1974. Calcareous nannoplankton and the age of the Globigerina silts of the western approaches of the channel: Geol. Mag., v. 111, p. 303-306.

Perch-Nielsen, K., 1972. Remarks on late Cretaceous to Pleistocene coccoliths from the North Atlantic. In Laughton, A.S., Berggren, W.A., et al., Initial Reports of the Deep Sea Drilling Project, Volume 12: Washington (U.S. Government Printing Office), p. 1003-1069.

Poore, R.Z. and Berggren, W.A., 1975. Late Cenozoic planktonic foraminiferal biostratigraphy and paleoclimatology of Hatton-Rockall Basin: DSDP Site 116: J. Foram. Res., v. 5, p. 270-293.

Schrader, H.-J., 1973. Cenozoic diatoms from the northeast Pacific, Leg 18. In Kulm, L.D., von Huene, R., et al. Initial Reports of the Deep Sea Drilling Project, Volume 18: Washington (U.S. Government Printing Office), p. 673797.

Schrader, H.-J. and Burckle, L.H., in press. Marine diatom biostratigraphy, its correlation to other microfossil zonations and to the paleomagnetic record. In Riedel, W.R. and Saito, T. (Eds.): Symposium "Marine Plankton and Sediments," Kiel.

Sclater, J.G., Jarrard, R.D., McGowran, B., and Gartner, S., Jr., 1974. Comparison of the magnetic time scales since the late Cretaceous. In von der Borch, C.C., Sclater, J.G., et al., Initial Reports of the Deep Sea Drilling Project, Volume 22: Washington (U.S. Government Printing Office), p. 381-386.

Talwani, M. and Eldholm, O., in press. Evolution of the Norwegian-Greenland Sea.

Worthington, L.V., 1970. The Norwegian Sea as a Mediterranean basin: Deep-Sea Res., v. 17, p. 77-84. 